\title{
POTENSI WILAYAH SEBAGAI KARAKTER VISUAL DALAM DESAIN BATIK GIRILAYU
}

\author{
Desy Nurcahyanti ${ }^{1)}$, Agus Sachari ${ }^{2}$, Achmad Haldani Destiarmand ${ }^{3)}$ \\ ${ }^{1}$ Fakultas Seni Rupa dan Desain, Institut Teknologi Bandung \\ e-mail: desynurcahyanti@students.itb.ac.id \\ ${ }^{2}$ Fakultas Seni Rupa dan Desain, Institut Teknologi Bandung \\ e-mail: aasachari@yahoo.com \\ ${ }^{3}$ Fakultas Seni Rupa dan Desain, Institut Teknologi Bandung \\ e-mail: achmadhaldani@yahoo.com
}

\begin{abstract}
The 4.0 industrial revolution currently offers traditions. Those offer options for chose to survive, join, or merge. Various forms of technology are offering unnecessity because the community has a system and local wisdom that keeps the form of tradition in its place. One of tradition form that's facing on offer is batik in Girilayu. Pattern character basic on regional potencies as a characteristic of Girilayu's batik design. Meanwhile, the specific purpose of this research is explaining the background of batik designers in Girilayu when making design development, to expose and promote the regional character in the 4.0 industrial revolution era today. The focus of the research problem includes changes and design innovations carried out by Girilayu's batik designers, within the last three years, from 2016 until the middle of 2019. The research method used qualitative with a hermeneutic approach through findings that shows visual characters of Girilayu batik. That appeared as a representation of Girilayu's community still maintains cultural nobility by exploring regional potencies as batik's characteristic.
\end{abstract}

Keywords: batik, character, design, Girilayu, visual.

\section{PENDAHULUAN}

Kemajuan teknologi, kecepatan data serta informasi telah membentuk ulang kebudayaan manusia secara global. Pilihan terbaik adalah menyesuaikan dengan perubahan atau punah. Secara harfiah kebudayaan bersifat dinamis bukan statis (Straubhaar, 2016). Menyesuaikan bukan berarti merubah wujud secara total agar diterima, dengan menyematkan teknologi tanpa pertimbangan matang, sehingga menimbulkan kesan keterpaksaan. Kebudayaan selalu berubah wujud menyesuaikan zaman dan kebutuhan manusia yang tidak terbatas, terutama dalam ranah primer atau utama, yakni sandang, pangan, dan papan. Bentuk dan sifat yang harus mengikuti perubahan tersebut adalah tradisi, terutama dalam sandang.

Perubahan pada tradisi menjadi diskusi akademik intelektual yang menarik hingga, terkait mempertahankan bentuk, memberi tambahan, atau mempertahankan dengan penyajian mutakhir. Batik Indonesia telah mendapat pengakuan dari badan internasional UNESCO sebagai warisan dunia tak benda, bukan berarti dalam posisi aman dan terjaga keberlangsungannya. Proses dan upaya perlu dilakukan oleh berbagai elemen dalam masyarakat, untuk menjaga keberlangsungannya dengan berbagai cara, tanpa merusak makna. Kurun sepuluh tahun merupakan waktu untuk mengevaluasi dengan melihat daya tahan dan kelayakan batik untuk tetap memperoleh pengakuan atau perlu ditinjau ulang karena melemah dari posisi sebelumnya (Nurcahyanti, 2018). Kelemahan tersebut muncul pada citra batik di kalangan masyarakat Indonesia. Batik diposisikan sebagai busana khas dengan beragam modifikasi. Fungsi batik sebagai wastra kaya makna dan proses, secara perlahan diaplikasikan ulang sebagai produk fesyen. Hal tersebut menyebabkan kedalaman makna menghilang, karena tenggelam dalam kemasan komersial yang memposisikan batik menjadi sekadar komoditas.

Cara masyarakat merespon batik saat ini adalah tepat, jika dilihat dari perspektif transformasi. Masyarakat mulai memperkenalkan batik pada anak usia dini dengan workshop teknik colet, mewarnai gambar, dan lomba peragaan busana. Motif batik ditampilkan pada lukisan, lantai rumah, piring makan, sepatu bahkan kue bolu. Latar belakang memunculkan motif batik dalam berbagai format adalah kebaruan. Kata kunci tersebut ditengarai muncul, karena masya- 
rakat jenuh jika batik hanya digunakan untuk keperluan fungsional tradisi. Pengenalan dalam berbagai rupa berusaha membentuk memori kolektif, bahwa batik merupakan bagian kehidupan sehari-hari masyarakat. Permasalahan muncul ketika esensi batik sebenarnya tidak terlihat, tertutup oleh variasi bentuk. Kesadaran masyarakat untuk menjaga format tradisi mulai hilang, maka dimung-kinkan suatu waktu kelak hanya dapat menyaksikan keindahan proses dan karya wastra batik tradisi melalui diorama, pameran museum, sajian augmented reality, atau bahkan aplikasi digital semata. Beragam alasan dilontarkan bahwa menjaga originalitas adalah hal sia-sia. Kritik untuk beberapa pihak yang masih menjaga batik tradisi, dimaknai sebagai bentuk pertahanan keras kepala. Kebutuhan masyarakat saat ini bukan untuk memaknai tradisi, tetapi mengkonsumsi benda yang dapat digunakan sebagai medium eksistensi personal (Sachari, 2007).

Batik tradisi yang berkembang pada wilayahwilayah di luar kantong batik (Cirebon, Pekalongan, Yogyakarta, Surakarta (Solo), Lasem, dan Madura) perlahan berbe-nah mengikuti perubahan. Hal sederhana yang dilakukan adalah membangun karakter desain pada motif kontemporer untuk menyesuaikan selera pasar. Karakter batik mengikuti keinginan konsumen yang mayoritas menyu-kai produk dari tampilan visual. Karakter dibangun sebagai penciri estetik suatu produk, karya, atau artefak sekaligus penanda asal zona sosial maupun konseptual. Ornamentik dan isen-isen (isian motif pada batik) yang digunakan menyiratkan makna keberadaan serta bentuk norma pada masyarakat. Kain batik yang dikenakan seseorang pada tubuh merupakan sebuah penghormatan bagi diri dan orang lain pada ruang interaktif serta komunikasi sosial. Lembar kain batik meru-pakan rangkaian doa dari setiap tarikan garis dinamis dengan canting yang ditingkahi cairan malam panas. Batik yang melekat pada tubuh adalah sarana eksistensi dengan muatan pesan tersirat dari dan untuk seseorang.

Sentra batik di Girilayu merupakan wilayah tumbuh wastra tulis canting di luar klasifikasi persebaran batik pesisir dan pedalaman. Permasalahan tentang keberlanjutan menjadi perhatian pembatik di Girilayu sejak kurun waktu sepuluh tahun terakhir (2009 - 2019). Menurunnya minat konsumen untuk menggunakan batik tulis, menjadi alasan kuat para desainer batik di Girilayu untuk membuat inovasi dan pengembangan motif. Mereka memiliki kesadaran untuk tetap melanjutkan batik tradisi meskipun invasi tekstil motif batik dari berbagai penjuru dunia, terutama Cina terus berdatangan. Kesadaran tersebut adalah tetap menjaga originalitas dalam hal proses, pemaknaan, dan fungsi. Hal tersebut selaras dengan wacana transformasi yang menggemakan perubahan sebagai keniscayaan, karena tidak ada yang mampu mempertahankan format asli tradisi secara utuh. Respon perubahan pada desain kontemporer batik di Girilayu adalah jalan keluar yang dipertimbangkan melalui kesepa-katan bersama. Mereka memandang bahwa karakter tradisi harus dipertahankan, karena menjadi rumus yang akan dilanjutkan oleh generasi berikutnya. Karakter adalah nyawa, sehingga bisa dipadankan pada tubuh atau bentuk manapun. Sedangkan, originalitas yang terdapat pada pakem batik Girilayu ditempatkan pada posisi utama untuk panduan pengembangan. Atas dasar uraian tersebut, maka karakter visual desain batik Girilayu dengan dasar potensi wilayah menarik dan layak diteliti. Temuan tentang karakter visual tersebut dapat digunakan sebagai panduan pengembangan wilayah, yang bermanfaat bagi peningkatan perekonomian dan kualitas hidup warga Desa Girilayu khususnya, serta masyarakat Kabupaten Karanganyar pada umumnya. Sektor terkait dengan penelitian ini antara lain sosial, budaya, pariwisata, dan ekonomi (Priambodo, 2013).

\section{KAJIAN LITERATUR}

Topik pengembangan desain batik telah diteliti sebelumnya. Mayoritas penelitian menitikberatkan pada eksplorasi bentuk yang terinspirasi hasil budaya atau artefak ber-sejarah yang menampilkan keragaman ornamentikal seperti candi, arsitektur keraton, dan iluminasi naskah kuno. Mendiskusikan batik saat ini telah masuk ke ranah global, terutama dari segi teknik dan proses. Perbedaan batik dari Indonesia dengan batik yang berkembang di negara lain adalah kedalaman makna filosofisnya. Setiap helai batik di Indonesia diwujudkan sebagai ekspresi visual layaknya karya seni. Setiap lembar batik tulis adalah karya maestro tanpa gelar. Pengembangan desain batik yang telah diteliti sebelumnya oleh peneliti dari berbagai negara, menjabarkan aspek yang mengarah pada kepentingan industri komersil dengan kualifikasi produk untuk konsumsi gaya hidup dan fesyen kelas atas.

Diversifikasi produk batik yang dikembangkan sebagai hasil penelitian beragam, sehingga wastra canting ini diposisikan sebagai pelengkap estetik guna memunculkan nuansa etnik. Fungsi kain batik secara tradisi awalnya sebagai pelengkap ritual upacara adat masyarakat, saat ini berubah menjadi material 
multifungsi yang dapat dibentuk sebagai benda pakai keseharian dan bersifat non sakral. Degradasi makna terjadi, oleh beberapa pihak hal tersebut dimaknai sebagai transformasi tradisi dan kewajaran. Konsep yang dipahami beberapa pihak tersebut adalah tradisi tidak dapat mempertahankan originali-tasnya, karena berbagai disrupsi menuntut untuk menyesuaikan diri. Perubahan bukan hal untuk dilawan tetapi memunculkan ide serta inovasi kebaruan. Fleksibilitas batik sebagai benda fungsional memunculkan resistensi yang baik untuk keberlanjutannya.

Stephen T. F. Poon dari Taylor's University Malaysia, dalam hasil penelitian-nya berjudul The journey to revival: Thriving batik design revolutionary in contemporary lifestyle and fashion atau diterjemahkan bebas menjadi perjalanan menuju kebangkitan: desain batik revolusioner yang berkembang dan potensinya dalam gaya hidup kontem-porer dan fesyen; menyoroti tentang ke-beradaan keberlanjutan Batik Malaysia. Perspektif industri menjadi sudut pandang yang berbeda untuk melihat posisi batik tradisi Malaysia. Fesyen kontemporer yang memanfaatkan batik sebagai elemen estetik harus tetap mempertimbangkan keberadaan batik tradisi. Batik diposisikan dalam industri fesyen harus membuat merk (brand) yang berbeda dari tradisi, sehingga masyarakat teredukasi dengan keberadaan batik fesyen sebagai alternatif. Hal tersebut dipahami oleh konsumen sebagai upaya pihak industri untuk mendukung pelestarian batik tradisi (Poon, 2017). Pokok bahasan penelitian pada pengembangan batik sebagai elemen motif pada skala industri besar tanpa mengesam-pingkan keberlanjutan batik tradisi. Karakter khusus untuk pengembangan desain motif batik pada industri yang dimaksud tidak diuraikan secara jelas.

H. Prastawa dan R. Purwaningsih dari Teknik Industri Fakultas Teknik Universitas Diponegoro, dalam hasil penelitian Affective design identification on the development of batik convection product atau identifikasi desain afektif pada pengembangan produk konveksi batik, kurang lebih sama dengan Poon yang mengulas pengembangan batik dari perspektif industri. Perbedaan dengan hasil penelitian Prastawa dan Purwaningsih adalah tentang nilai afektif atau pertimbangan yang mempengaruhi sikap generasi $X$ (kelahiran 1966-1976) dan Y (kelahiran 1977-1994) dalam memilih produk batik konveksi. Identifikasi tersebut menggunakan metode khusus yakni teknik Kansei, yang digunakan untuk menilai keunggulan suatu produk berdasarkan teknologi yang diterapkan. Konsumen dengan pola pikir teknik Kansei memandang produk batik konveksi dengan sentuhan teknologi lebih baik. Teknologi tersebut tidak sebatas material yang nyaman dengan keunggulan menyerap kadar air atau lebih berkilau, tetapi juga pada proporsi potongan atau model menyesuaikan berbagai bentuk badan, serta warna atau pigmentasi khusus untuk memunculkan kesan mewah pada tampilan produk batik tersebut. Temuan berdasarkan hasil survei menunjukkan bahwa faktor keunggulan warna mampu mengako-modir selera modern, dewasa, praktis, elegan, menarik, kasual, dan kreatiflah yang menjadi pertimbangan tertinggi untuk membeli produk batik konveksi (Prastawa, 2017). Secara spesifik identifikasi warna yang dimaksud tidak disebutkan pada hasil penelitian.

Pengembangan penerapan motif batik pada rupa fungsi lain di luar busana menjadi penelitian menarik oleh Ayn Sayuti dan Mas Ayu Zainal dari Universiti Teknologi MARA Malaysia, berjudul From culture to innovative product: batik design in porcelain wares atau Dari budaya ke produk inovatif: Desain batik di peralatan makan porselen (keramik). Ke-duanya menguraikan temuan tentang inovasi atau kebaruan yang diterapkan pada produk peralatan makan porselen dengan desain motif Batik Merbok dari Kedah. Hasil dari proses desain dengan menggunakan software tiga dimensi menunjukkan bahwa peralatan makan porselen yang diberi sentuhan desain motif Batik Merbok mampu memunculkan citra elegan, keunikan, dan kemewahan. Produk dengan sentuhan lokal tersebut memiliki peluang pasar dan selera interna-sional (Sayuti, 2018). Pada uraian hasil tidak dijelaskan spesifikasi latar belakang untuk menyebut citra elegan, unik, dan mewah pada produk peralatan makan porselen dengan aplikasi pengembangan motif Batik Merbok secara visual.

Pelatihan pengembangan desain batik sebagai sebuah upaya peningkatan kemampuan wirausaha atau design batik development training as an effort to empower business, hasil pengabdian masyarakat oleh Mulyanto dari Program Studi Pendidikan Seni Rupa Fakultas Keguruan dan IImu Pendidikan Universitas Sebelas Maret (UNS), merumus-kan prinsip dasar pengembangan desain batik bagi industri skala kecil. Prinsip dasar ter-sebut merupakan komponen yang menetuan keberhasilan penyelenggaraan pelatihan pengembangan desain batik, antara lain: (1) para peserta memiliki motivasi kuat dan respon baik selama pelatihan berlangsung; (2) pelatihan dilaksanakan pada tempat produksi batik milik peserta pelatihan, sehingga dapat mempraktikkan secara langsung; (3) fasilitator atau pelatih memiliki kompetensi, 
mengetahui karakter peserta pelatihan serta kondisi sosial budaya masyarakat, dan paling utama memiliki kemampuan berkomunikasi yang baik; dan (4) pelaksanaan kegiatan pelatihan merupakan aktivitas yang dipraktikkan secara langsung bersamaan dengan kegiatan produksi, menggunakan pendekatan edukatif, mengembangkan kreatifitas peserta sesuai dengan kondisi sosial-budaya masyarakat setempat, dan potensi atau sumber daya yang telah dimiliki oleh industri (Mulyanto, 2013). Hasil penelitian tidak mengarah pada karakter khusus produk batik, tetapi uraian hal yang dapat dicapai untuk memajukan usaha batik skala industri kecil.

Pengembangan motif batik dengan teknik khusus diuraikan oleh Mursidah Waty dalam artikel berjudul Airbrush Karawo Batik Design atau Desain Batik Karawo dengan Teknik Airbrush. Penelitian tersebut bertujuan untuk mengetahui karakter produk hasil kolaborasi bordir Karawo dengan aplikasi motif batik menggunakan teknik airbrush. Hasil perpaduan dua macam teknik tersebut memberikan nilai estetik dan sebagai representasi kebaruan untuk diterapkan pada busana khas Gorontalo. Simpulan penelitian mengarah pada hal ikhwal teknis visualisasi, dan analisis SWOT atau strengths, weakness, opportunities, threats- kelebihan, kekurangan, peluang, resiko/ -ancaman (Waty, 2019). Karakter hasil pengembangan bordir Karawo dengan aplikasi motif batik menggunakan teknik airbrush tidak diuraikan secara detail.

Pengembangan desain pada batik ditinjau dari sudut pandang upaya konservasi, diuraikan Rodia Syamwil dari Universitas Negeri Semarang (UNNES), pada penelitian-nya berjudul Conservation of batik: Consep-tual framework of design and process development. Penelitian ini melihat bahwa keberadaan batik dengan proses printing, polusi yang ditimbulkan pada proses batik, dan desain-desain baru keluar pakem (aturan khusus) batik, merupakan konsekuensi yang terjadi akibat tuntutan industri kreatif. Konservasi batik menjadi solusi permasalahan yang dihadapi batik tradisi dari aspek teknik, proses, dan motif. Selera konsumen dapat dipenuhi dengan kreatifitas pengembangan produk khususnya motif batik. Konservasi batik yang diuraikan meliputi empat aspek, yaitu perlindungan (kekayaan intelektual), promosi/ sosialisasi, mengelola, dan melanjut-kan. Syarat konsep konservasi yang diterapkan pada batik menurut hasil penelitian Rodia, antara lain: (1) nilai tradisional dan autentisitas (keaslian), (2) nilai dari makna filosofis, (3) proses ramah lingkungan dengan minim residu/ sisa, (4) konservasi sebagai sumber ide desain, dan
(5) memperkenalkan kembali batik klasik dalam berbagai bentuk varian kreasi melalui reproduksi motif (Syamwil, 2018). Temuan penelitian tidak membahas perihal karakter yang menjadi panduan atau harus dimunculkan dalam konsep konservasi batik tersebut.

Bentuk penerapan ragam permainan anakanak tradisional dalam motif batik sebagai upaya pengembangan diteliti oleh Indrayana, Karju, dan Yustana dari Institut Seni Indonesia Surakarta, dengan judul Indonesian traditional toys and the development of batik motifs. Penelitian ini bertujuan untuk menguraikan solusi perma-salahan mainan tradisional di wilayah Klaten dan Magelang yang kurang diminati. Kebaruan yang dilakukan selain modifikasi bentuk juga penerapan pada motif batik. Para peneliti menyadari, mainan tradisional merupakan medium untuk edukasi dan stimulan bagi tumbuhnya kreatifitas pada anakanak. Kehadiran permainan modern dengan basis digital saat ini mulai menggeser keberadaannya. Pengetahuan bentuk-bentuk ragam permainan anakanak tradisional Jawa jarang dipelajari. Fleksibilitas batik sebagai medium untuk menyampaikan berbagai macam pesan dimanfaatkan sebagai fasilitas promosi. Langkah inovatif dengan menerap-kan bentuk permainan anak dalam motif batik, sebagai cara untuk memperkenalkan kembali permainan anak-anak tradisional kepada masyarakat secara estetik dan visual (Indrayana, 2016). Penelitian tersebut tidak menguraikan karakter yang muncul untuk produk batik dengan bentuk permainan anak-anak tradisional. Alternatif desain batik yang dibuat sebatas memperkaya khasanah motif batik sekaligus sebagai medium visual tentang permainan anak-anak tradisional yang mulai ditinggalkan masyarakat di Klaten dan Magelang saat ini.

Penelitian berikutnya oleh Murwati dan Masiswo dari Balai Besar Kerajinan dan Batik Yogyakarta, menguraikan hasil pengembangan desain motif batik Melayu melalui teknik rekayasa atau rancang bangun motif dan proses terutama komposisi warna. Rancang bangun yang dimaksud adalah dengan memanfaatkan unsur-unsur seni dan keterampilan etnis Melayu untuk menciptakan motif batik menarik serta mampu memenuhi selera konsumen. Karakter ragam hias Melayu menjadi poin utama pengembangan desain batik. Pendekatan estetik dilakukan untuk mencapai keindahan dalam unsur desain. Keindahan terwujud dengan mem-perhatikan unsur desain, meliputi irama, variasi, keseimbangan, kesatuan, dan harmoni. Hasil penelitian tersebut mengungkap bahwa batik Melayu 
yang digemari oleh konsumen adalah naturalis sebagai karakter tunggal (Murwati, 2013). Sejalan dengan penelitian Murwati dan Masiswo; oleh Mandegani, Setiawan, Atika dan Haerudin dari instansi yang sama (BBKB) menguraikan hasil analisis tentang karakter batik mayoritas dibentuk oleh selera konsumen, bukan berdasarkan ekspresi estetik semata (Mandegani, 2013).

Kajian estetika motif batik Girilayu Kabupaten Karanganyar oleh Sugeng Wardoyo dari Institut Seni Indonesia Yogyakarta, merupakan penelitian yang memiliki korelasi dengan karakter visual dalam batik Girilayu. Aspek struktur dan gaya menjadi poin pembahasan seputar estetika yang terdapat dalam pengembangan batik Girilayu (Wardoyo, 2019). Penelitian tersebut belum secara detail mengulas mengenai potensi wilayah sebagai faktor utama yang mempengaruhi pengembangan motif batik di Girilayu. Celah tersebut menjadi topik menarik untuk diurai lebih mendalam pada penelitian ini.

\section{METODE PENELITIAN}

Penelitian ini menggunakan kualitatif; dimana peneliti sebagai instrument yang bertanggungjawab penuh terhadap pengum-pulan data di lapangan. Data dihimpun dengan wawancara, studi pustaka, survei lapangan, dan focus group discussion. Data diolah dan dianalisis dengan metode triangulasi untuk menghasilkan data objektif sesuai dengan lingkup permasalahan yakni karakter visual pengembangan desain batik Girilayu berdasarkan potensi wilayah. Data tersaji sebagai kelanjutan dari penelitian lain sejenis yang belum menampilkan secara khusus karakter desain motif batik Girilayu dari pengaruh aspek potensi wilayah.

Pertimbangan pemilihan wilayah Girilayu sebagai daerah penelitian adalah permasa-lahan yang muncul di sentra pembatikan tersebut relevan dengan kondisi saat ini. Topik merawat tradisi dengan berbagai kendala, pada akhirnya memunculkan kebaruan produk dengan akar tradisi di suatu daerah, di antaranya Girilayu. Terletak di wilayah administratif Kabupaten Karanganyar Jawa Tengah, Girilayu merupakan desa kecil penghasil batik berkualitas. Para pembatik membentuk sistem, strategi, dan cara untuk melanjutkan batik tradisi, salah satunya melalui pengembangan desain motif yang memunculkan ciri khas wilayah Girilayu. Upaya para desainer batik Girilayu bukan hal baru di wilayah kajian perbatikan nusantara, namun menjadi kebaruan untuk menjaga usaha batik tradisi dalam skala kecil di wilayah
Girilayu, melalui serangkaian pertimbangan dan permasalahan penting menyangkut kerta keberlanjutan serta konsistensi usaha.

\section{HASIL DAN PEMBAHASAN}

Pengembangan desain bagi pembatik Girilayu merupakan hal yang dilakukan dalam kurun waktu 10 tahun terakhir. Peningkatan jumlah desain batik baru meningkat sejalan dengan kepopuleran batik, pasca diresmikan sebagai warisan dunia tak benda oleh UNESCO. Permintaan produk batik meningkat, khususnya tekstil motif batik, yang sebenarnya jika dilihat dari segi proses tidak berhak disebut batik. Pengertian harfiah batik adalah produk dengan motif ornamentikal khas stilasi atau penggayaan, dibuat dengan teknik tutup celup mengguna-kan malam atau lilin sebagai perintang warna, yang ditorehkan dengan alat canting atau cap tembaga. Perihal penerapan malam menggunakan teknik dingin yaitu mencairkan malam dengan proses kimia, merupakan inovasi untuk efektifitas produksi.

Motif yang diproduksi para pembatik Girilayu awalnya pesanan dari para juragan batik besar di Surakarta (Solo), terutama motif klasik. Para pembatik tersebut tidak memiliki keleluasaan untuk mengembangkan desain, karena pada dasarnya batik yang dibuat sudah ditentukan oleh produsen, dan para pembatik bertindak sebagai buruh sanggan dengan tugas nglowong (mencanting sesuai dengan lekuk garis pola pensil pada kain mori), nerusi (mencanting bagian dalam kain untuk mempertegas motif), serta nembok (mencanting dengan memblok penuh bagian tertentu pada motif). Lambat laun para pembatik menyadari peluang pengembangan desain sebagai cara untuk memperkenalkan kemampuan membatik dengan kualitas prima kepada masyarakat luas. Pada tahun 2016 sampai 2019 merupakan masa puncak pengembangan desain motif batik Girilayu dengan olah komposisi bentuk bersumber ide kondisi geografis wilayah pegunungan, area perkebunan yang luas, hasil perkebunan serta pertanian, dan lokasi wisata unggulan Kabupaten Karanganyar berupa ziarah ke tiga makam besar keluarga besar Mangkunegaran. Nama Girilayu kurang dikenal dibanding Giriloyo yakni daerah sentra pembatikan di Yogyakarta berdekatan dengan Imogiri (makam Rajaraja dari Mataram Islam, yaitu Kasultanan Yogyakarta, Kasunanan Sura-karta, dan Puro Paku Alaman). Pengem-bangan desain batik Girilayu diangkat sebagai sumber inspirasi motif kontemporer, sekali-gus sebagai sarana untuk memperkenalkan wilayah 
Girilayu, serta ragam potensi yang terdapat di tempat tersebut.

Karakter didefinisikan sebagai sifat, ciri, hal yang membedakan, dan keunggulan yang dalam makna filosofis serta dapat dilihat dari wujud fisik secara visual. Kedalaman makna mempengaruhi wujud visual secara holistik. Pesan yang akan disampaikan melalui sebuah motif batik berkorelasi dengan wujud yang ditampilkan, meliputi komposisi bentuk, garis, warna, dan harmonisasi tata letak isian. Pengembangan desain motif batik Girilayu berdasarkan potensi wilayah merupakan kesepakatan yang dibuat antar masyarakat pembatik dan tokoh masyarakat, kemudian desainer bertugas menerjemahkan indikator-indikator tersebut.

Potensi wilayah yang dimaksud pada penelitian ini adalah kemampuan suatu daerah yang dapat dikembangkan. Girilayu secara geografis memiliki potensi di sektor perkebunan, pertanian, dan kondisi alam yang mendukung aktivitas perekonomian wilayah tersebut. Pola pikir masyarakat dan kondisi sosial terbentuk karena pengaruh lingkungan tempat tinggal, sebagai area interaksi terbesar dalam keseharian. Di luar keunggulan tersebut kebudayaan yang tumbuh pada masyarakat Girilayu mempengaruhi citra visual pengembangan desain batik. Tiga hal yang membentuk kebudayaan yakni pola pikir, kondisi sosial, dan produk sebagai hasil interaksi nyata antara gagasan dengan kebutuhan masyarakat.

Desain batik Girilayu selama ini diidentikan dengan batik yang dibuat dalam lingkup Mangkunegaran (istana). Berdasarkan penuturan sesepuh dan tokoh masyarakat Girilayu, kemampuan turun menurun menekuni batik merupakan warisan dari nenek moyang yang bertugas sebagai pembatik Girilayu. Secara administratif Girilayu adalah wilayah praja atau setara dengan kecamatan saat ini. Tumenggung ditugaskan untuk memimpin wilayah Girilayu. Keahlian membatik yang dimiliki oleh Tumenggung sejak zaman KGPAA Mangkunegoro I (Raden Mas Said atau Pangeran Samber Nyawa) diajarkan pada penduduk sekitar yang mengabdi padanya. Keahlian tersebut lambat laun menyebar menyeluruh di wilayah Girilayu. Kualitas pembatikan di Girilayu tergolong bagus secara visual, rapi, dan halus, maka permintaan untuk produksi batik dari berbagai daerah meningkat. Khususnya para pejabat istana Mangkunegaran yang sering memesan sebagai busana untuk pelaksanaan ritual tradisi seperti pernikahan dan kematian. Bagi masyarakat Jawa, peristiwa pernikahan dan kematian bersifat sakral sebagai daur hidup yang penyelenggaraannya melibatkan masya-rakat luas dan kerabat terkait. Pihak tuan rumah tidak ingin menyia-nyiakan kesempatan tersebut sebagai momen terbaik, terlebih dalam menjamu tamu yang hadir. Busana dan penampilan dalam dua acara besar tersebut menjadi hal penting yang dipersiapkan secara paripurna. Kualitas dan visual batik yang digunakan menentukan status sosial penyelenggara acara atau tuan rumah. Batik berkualitas yang digunakan dapat meningkatkan pamor tuan rumah dan beberapa standar pengakuan disematkan padanya berdasarkan pengakuan tamu yang hadir.

Batik adalah sarana penghantar doa dan pengharapan luhur dari pembuat atau pemakai. Pemilihan batik berkualitas menjadi pertimbangan penting, terutama desain motif sebagai perwujudan doa dengan abstraksi pada makna filosofis. Masyarakat memasukkan potensi wilayah terdekat dengan keseharian mereka sebagai motif batik sebagai ciri khas, di antaranya pada motif Tugu Tri Dharma yang terinspirasi dari monumen Tri Dharma pada Astana Mangadeg, sekaligus ikon wisata ziarah di Kabupaten Karanganyar; motif Gapura Tri Dharma terinspirasi dari gapura masuk sebelum komplek Tugu Tri Dharma dan Makam Mangkunegoro I-III; Duren Matesih dan Manggisan terinspirasi potensi unggulan perkebunan; dan Mbok Semok sebagai motif representasi keberadaan para pembatik perempuan di Girilayu mewakili potensi sumber daya manusia.

Potensi wilayah Girilayu tidak hanya yang terlihat secara visual, kemudian diwujudkan secara simbolis dalam motif batik oleh para desainer. Hasil diskusi dan wawancara dengan pembatik Girilayu menyatakan bahwa suasana jiwa secara kontemplatif turut menentukan wujud motif yang mereka buat, tetapi tidak dominan. Pengembangan motif batik oleh para desainer Girilayu tidak sekedar mengejar kualitas estetik semata, keindahan secara visual, dan setelah proses produksi oleh para pembatik masuk tahapan berikutnya yakni pemasaran, laku dan diminati konsumen; kemudian produksi ulang karena permintaan meningkat (repeat order) menjadi indikator keberhasilan. Makna keberhasilan bagi masyarakat Girilayu adalah ketika pesan dan maksud yang disampaikan melalui motif batik dapat dipahami serta diapresiasi baik oleh konsumen atau pihak berkompeten mengenai batik seperti pakar, komunitas pecinta batik, desainer fesyen, dan akademisi peneliti. Motif tersebut mampu menjadi perantara komunikasi lintas bidang untuk merealisasikan secara nyata wacana pembangunan Desa Girilayu yang berdikari. 


\section{KESIMPULAN}

Berdasarkan hasil analisis dan pembaha-san menunjukkan bahwa potensi wilayah sebagai karakter visual dalam pengembangan desain Batik Girilayu berperan dominan. Karakter tersebut tercermin dalam pemilihan elemen atau ornamentik pendukung pembentuk pola desain motif batik. Karakter visual tersebut dapat dirumuskan sebagai berikut:

(1) Klasik, dengan menggunakan pewarnaan khas batik gaya Mangkunegaran, pengaruh ini berasal dari kebiasaan leluhur yang diwariskan turun temurun pada pembatik Girilayu hingga saat ini.

(2) Otentik, masih mempertahankan pakem stilasi motif termasuk untuk figur manusia karena pengaruh ajaran Islam, sebagai contoh pada motif batik Mbok Semok, sosok pembatik perempuan digayakan sehingga tidak menyerupai wujud sebenarnya.

(3) Lokal, mengangkat bentuk-bentuk, nilai, dan norma yang diyakini serta dekat dengan keseharian masyarakat Girilayu.

(4) Elegan, terlihat pada garis yang rapi, halus, dan konsisten. Hal tersebut memperlihatkan kemampuan (skill) pembatik Girilayu yang baik, sebagai wujud proses pembelajaran dan regenerasi yang baik dari para pendahulu. Standar kualitas disepakati berdasarkan pengalaman, wawasan, dan arsip batik warisan dari orang tua pembatik.

(5) Dokumentatif, batik yang dibuat sebagai sarana dokumentasi visual perubahan dan hasil-hasil kebudayaan yang ada di Girilayu.

\section{DAFTAR PUSTAKA}

Indrayana, B. , Karju, dan Yustana, P. (2016). "Indonesian Traditional Toys and the Development of Batik Motifs, Journal of Arts and Humanities, 5(6), 26-36.

Mandegani, G. B. , Setiawan, J. , Atika,V. , dan Haerudin, A. (2018). "Persepsi Kualitas Batik Tulis", Jurnal Dinamika Kerajinan dan Batik, 35(2), 75-84.

Mulyanto, (2013). "Batik Design Development Training as an Effort to Empower Business", Research on Humanities on Social Sciences, 3(6), 22-30.

Murwati, E. S. dan Masiswo. (2013). "Rekayasa Pengembangan Desain Motif Batik Khas Melayu", Jurnal Dinamika Kerajinan dan Batik, 30(2), 67-72.
Nurcahyanti, D. dan Affanti, T. B. (2018). "Pengembangan Desain Batik Kontemporer Berbasis Potensi Daerah dan Kearifan Lokal", Jurnal Sosioteknologi, 17 (3), 391402.

Poon, S. T. F. (2017). “The Journey to Revival: Thriving Revolutionary Batik Design and Its Potential in Contemporary Lifestyle and Fashion", International Journal of History and Cultural Studies (IJHCS), 3(1), 48-59.

Prastawa, H. dan Purwaningsih, R. (2017). "Affective Design Identification on the Development of Batik Convection Product", IOP Conf. Series: Materials Science and Engineering, 273, 1-7.

Priambodo, H. (2013). “Tradisi Ziarah Makam sebagai Pengembangan Ekonomi Masyarakat di Desa Girilayu (Studi Kasus Makam Pangeran Sambernyowo di Astana Mengadeg Desa Girilayu Kecamatan Matesih Kabupaten Karanganyar)", SOSIALITAS Jurnal IImiah Pendidikan Sosio Antropologi, 3(1), 1-5.

Sachari, A. (2007). Budaya Visual Indonesia. Jakarta: Penerbit Erlangga.

Sayuti, A. dan Zainal, M. A. (2018). "From Culture to Contemporary Product: Batik Design in Porcelain Wares", Malaysian Journal of Suistainable Environment, 5(2), 27-42.

Straubhaar, J., LaRose, R. , dan Davenport, L. (2016). Media Now: Understanding Media, Culture, and Technology. USA: Cengage Learning.

Syamwil, R. (2018). "Conservation of Batik: Conseptual Framework of Design and Process Development", AIP conference Proceedings, 1941, 1-10.

Wardoyo, S. (2019). "Kajian Estetika Motif Batik Girilayu Kabupaten Karanganyar", CORAK Jurnal Seni Kriya, 7(2), 117-126.

Waty, M. (2019). "Airbrush Karawo Batik Design", Journal of Social Science Studies, 6(1), 128-140. 